\title{
Information-Seeking Behavior of Securities Analysts: Individual and Institutional Influences, Information Sources and Channels, and Outcomes
}

\author{
Nancy Sadler Baldwin \\ Morgan Stanley and Co., Inc., 1585 Broadway, 38th Floor, New York, NY 10036-8293. \\ E-mail: nbaldwin@ms.com \\ Ronald E. Rice* \\ School of Communication, Information and Library Studies, Rutgers University, 4 Huntington St., \\ New Brunswick, NJ 08903-5067. E-mail: rrice@scils.rutgers.edu
}

\begin{abstract}
Information technology and the need for global information are constantly changing the way securities analysts, one kind of knowledge worker, obtain, manipulate, and disseminate information. This study develops and tests a general model, with specific hypotheses, that individual characteristics and institutional resources influence the information sources and communication channels that individuals use, that use of these sources and channels influences the outcomes of analysts' activities, and that, therefore, individual characteristics and institutional resources both directly and indirectly influence the outcomes. The data for this study were collected through a telephone survey administered to a random sample of 100 securities analysts from 40 of the largest investment banking firms in the United States and the United Kingdom. The results show that individual characteristics have little influence on the information sources and communication channels used by analysts, and thereby do not have a significant influence on the outcomes of analysts' information activities. Institutional resources do have a significant influence on the information sources and communication channels analysts use, but also have a direct influence on outcomes, and thereby play a significant role in analysts' information activities. The conclusion discusses implications of these findings for securities analysts, institutional and retail investors, schools of library and information science, and practicing information professionals.
\end{abstract}

\section{Introduction}

On Wall Street and in the global marketplace of the 1990 s, information is power and money; indeed, Wall

\footnotetext{
* To whom all correspondence should be addressed.
}

Received January 25, 1996; revised June 20, 1996; accepted June 20, 1996.

(C) 1997 John Wiley \& Sons, Inc.
Street functions almost entirely on information. The U.S. financial services industry underwent a revolution in the 1980s that has resulted in a dramatically restructured industry in the 1990s. First, the nature of Wall Street's business changed considerably as commission rates fell due to deregulation of the markets and fierce competition within the industry. Second, the deregulation of London's securities markets in 1986 and the current attempt to restructure the European Economic Community, has generated European interest in foreign investors. Emerging markets in Eastern Europe, Asia, and Latin America are also providing new opportunities for investments in foreign stocks, project financings, and privatizations. Third, the integration of new electronic systems into the market, and across national markets, has increased both the quality of information and the speed at which it is disseminated.

In addition, U.S. companies are rapidly globalizing and their international business operations are becoming a large portion of their revenue and earnings. Investment firms are committing themselves to broad-based financial services, such as global equity research, and sales and trading activities. New sources of information that cover global economic trends, international production and marketing data, and international mergers and acquisitions are needed. All these changes present Wall Street and securities analysts with new challenges.

Securities analysts form a distinctive group of information-seekers. Securities analysts are intelligent and motivated users of information. Every year top graduates of M.B.A. programs are hired as securities analysts by Wall Street firms. They are in the forefront in utilizing information systems that allow them to build forecasting models, create quantitative valuation models, and conduct "whatif " scenarios. These systems, in addition to improving 
the quality of investment research, are intended to increase an analyst's effectiveness and productivity. These systems are, to a degree, the predecessors of systems which will be used by students and professionals in other disciplines. The work of securities analysts is information intensive. With timeliness being essential, securities analysts are willing to pay large sums of money for the rapid delivery of information. It therefore seems useful to investigate the influences on, behavioral patterns of, and outcomes from, the information-seeking behaviors of securities analysts.

\section{User Studies}

We can better understand securities analysts' information-seeking behaviors by reviewing related research from prior user studies. Modern day user studies were developed in response to the growth in science and technology following World War II. They originated under the premise that effective information systems could be designed by identifying the information needs of user groups. By 1978, Crawford estimated that over 1,000 user studies had already been published.

\section{User Studies in the Sciences, Social Sciences, and Humanities}

The early studies on informal communication patterns among scientists and researchers are particularly relevant to this study in that they identify the importance of "gatekeepers" and informal communication within user groups (Ladendorf, 1970). Allen (1977) identified communication stars in work units in various technological organizations, who serve as gatekeepers that facilitate the flow of information from outside to their colleagues. Gatekeepers read more journals, have more external contacts, generate more ideas, and engage in more problem solving than non-gatekeepers. Gatekeepers not only provide professional information, but they also give practical and political advice. Metoyer-Duran (1993) notes research that concludes that "formal and informal ties to local and nonlocal institutions, organizations, or associations have higher rates of information use that do those who lack such affiliations"' (p. 117). Thus they play important roles, not the least of which is that they contribute to scientific performance by increasing the amount and variety of information consumed (Allen, 1969). Technological gatekeepers mediate information flow between internal and external, domestic and international, through their links to various networks of information sources (Metoyer-Duran, 1993). They may perform that role only for specific information categories, and perform two quite different functions: Limiting access to or restricting scope of information, and/or fostering innovation, change, and exchange or use of information (Metoyer-Duran, 1993).

Achieving effectiveness from information systems requires understanding of the crucial information role of those communication networks - our primary source for mediated information (Grosser, 1991). These networks reduce information overload, overcome personal limits on information acquisition and interpretation, and add value through intermediate evaluations and sense-making. The related informal communication patterns are unregulated and spontaneous, usually lateral, but often serving as links among hierarchical levels or as gatekeepers to other network groups, even external to the organization (such as technological gatekeepers, boundary-spanners, liaisons, and the "information rich"). These gatekeepers keep up more with professional literature, have more professional affiliations, more external oral contacts, and greater access to information sources in general, and can translate terms and norms across networks. These communication-rich roles develop informally over time, and generally foster greater innovativeness and performance (except for routine tasks). Weak ties (infrequent, but bridging different networks) are valuable because they do not require as much cost to maintain, yet expose one to new information. Network building is particularly important for managers, as it fosters more channels and thus more information and opportunities for action, and especially provides informal exposure to significant problems outside of formal channels (Katzer \& Fletcher, 1992).

Price (1963) identified the invisible college phenomenon when he suggested that a small group of scientists within any given research area monitors the changes taking place in their field by staying in contact with one another, both within and among groups (Crane, 1971; Cronin, 1982). Invisible colleges influence the communication of information before, during, and after meetings of professional associations (Garvey \& Griffith, 1968; Johns Hopkins University, 1969). Scientists who work for organizations that permit unrestricted travel are associated with greater productivity and with greater success in obtaining information (Shilling, Bernard \& Tyson, 1964). Being a gatekeeper not only increases one's status, but that higher status in turn increases one's likelihood of being an academic gatekeeper. The research of scientists of high rank is more likely to be initially selected and then read because of their authors' visibility in the scientific community (APA, 1963; Cole \& Cole, 1967; Menzel, 1966).

\section{User Studies of Public Libraries by Information-Seekers}

Studies about the use of public libraries are indirectly related to this study as securities analysts and other knowledge workers have access to local libraries. Berelson's 1949 study was one of the first to review major aspects of public library usage, although by 1977 there were still only a handful of public library studies that considered the characteristics of users (Zweizig \& Dervin, 1977). The late 1970s and early 1980s saw a renewed interest in how librarians provide reference service to the 
community. One such study showed that co-workers and professional journals are the most consulted information sources, and that the individuals did not use a library to obtain the information they need for their work (Prentice, $1980)$. Several studies found that people tend to use interpersonal sources - friend, relative, or neighbor - rather than the public library (Chen \& Hernon, 1982; Dervin, 1976; Wilson, 1977). Durrance (1984) found that $64 \%$ of her citizen group members used interpersonal sources, although $50 \%$ of the members said they used libraries when they needed to look for printed information.

\section{User Studies of Knowledge Workers and Managers}

Knowledge workers (including managers) continually search for new information. They monitor, store, and disseminate company and industry-related information. Their information-seeking behavior may be influenced by their environment. Due to information processing limitations and problem pressures, much organizational decision-making is largely "muddling through," satisficing with limited information, succumbing to time limits (Grosser, 1991, p. 385). The many bounds on rational decision-making include: Ambiguous goals defined incrementally, need to satisfice, availability of possible solutions and actions, and social, conflict, and political obstacles (Katzer \& Fletcher, 1992).

Securities analysts, like scientists and engineers, have long uninterrupted segments of time to spend on one study; CEOs and managers have only short segments of time to spend on any one issue. Most executives probably have a support staff to provide the information they need to make their decisions. On the other hand, securities analysts and scientists spend most of their time obtaining information and writing reports. Therefore, knowledge workers on opposite ends of the spectrum may exhibit different information-seeking behaviors.

Managers prefer oral, face-to-face communication, quick resolution favoring access and speed to accuracy, not necessarily rational decision-making because of the instability, conflict, and uncertainty of situations. However, these situations are constrained and structured by managerial roles (such as Mintzberg's interpersonal, informational, and decisional), managerial activities (such as Kotter's agenda setting and network building), decision-making (problem finding, decision-making, problem solving) and problem dimensions (or criteria for assessing relevance of information) (Katzer \& Fletcher, 1992). Individual managerial characteristics that influence information behaviors include tenure (greater use of intuition), cognitive style (affecting preference for and processing of information), personal biases in identifying and analyzing information (illusion of control, overconfidence in judgment, poor inferences, avoiding disconfirming information) (Katzer \& Fletcher, 1992).

Organizational "context effectively constrains a person's information behaviors" (Katzer \& Fletcher, 1992, p. 227). Organizational characteristics such as size, structure, goals, culture, production, politics, environment, organizational incentives for gathering information, emphasis on surveillance, risk aversion, and symbolic value of information all influence managers' use of information.

A number of studies during the past three decades address how knowledge workers obtain information from internal and external sources. Drott (1973) concluded that in information-rich environments, people decide for themselves how they will acquire information and what services they will use, probably choosing whatever is most convenient and accessible, regardless of cost. They should also be better prepared to make decisions and write reports. It also seems likely that they are more productive and satisfied with their outcomes. In their studies on how executives obtain information, Aguilar (1967), Collings (1968), and Keegan (1967) reached conclusions similar to those of Hofer's study of strategic planners: "In general, personal sources of data greatly exceed impersonal sources in importance. In this regard, subordinates were the greatest single source of information, while superiors and meetings were very poor sources of information" (Hofer, 1976, p. 264). It is important to note that these studies do not include libraries or information systems as information sources available to top management executives. In a study that examined how corporations acquired information concerning their strengths and weaknesses, Stevenson (1969, p. 31$)$ concluded that "formal sources were clearly the major source of information on the internal state of the organization, while personal sources were the major source of external information."

Choo and Auster's review (1993) proposed four primary stages in managerial use of information. First, organizational members need information to overcome members' cognitive limitations, and to reduce equivocality and uncertainty about perceived environmental conditions by making sense of available information. Thus, the environment represents informational resources on which organizations may be more or less dependent. Second, information needs in general develop in social and work contexts, such as managerial roles, as ways of making sense of one's progress toward goals; require both formal and informal information; and tend to place greater emphasis on source accessibility than quality. Third, these two processes foster increasing information needs by managers, motivated by immediate problems and preferably satisfied by personal observations, individuals as sources, and verbal media. Fourth, to that end, managers proactively engage in environmental scanning, especially market-related environmental sectors, through both internal and external, but preferably personal sources and rarely libraries or online databases. This scanning is influenced by firm size, managerial experience, and those perceptions of the environment, but not much by managerial job characteristics.

The knowledge workers of today must control information in a global environment. Multinational corporations 
are utilizing computer-based information systems to manage and monitor their global information resources (Selig, 1982). Most knowledge workers are computer literate, and perform their own research instead of, or in addition to, using an intermediary, such as a librarian. However, Hart and Rice (1991) found that foreign exchange traders' use of full-text and reference or numeric databases is different, and that using intermediaries may decrease the perceived value of the retrieved information.

\section{User Studies of Securities Analysts}

Several studies within the securities industry focus on analysts and their research. Opinion Research Corporation conducted a survey of securities analysts to determine what information sources they used in evaluating companies. Company reports were considered the most widely used general communication source, and personal conversations with company officials were considered the most valuable form of special communication. The written reports of securities analysts at other firms, followed closely by news, business, financial, and professional publications were the most frequently cited sources of non-company communication (Latane \& Tuttle, 1970).

The staff at Wall Street Letter conducted a survey of top securities analysts to determine what proportion of their time is spent on marketing and traveling to see clients, due to stiffer competition and the revenue needed to justify higher salaries. Although the survey found that the amount of time varies from firm to firm (on average top analysts spend $45 \%$ of their time marketing to clients), many of the analysts noted that excessive marketing can have a negative impact on their research (Top Analysts, 1986, p. 1).

Recent studies have discussed securities analysts' use of information in making forecasts. Other than stock recommendations, earnings forecasts are the most important work product of analysts. It has been shown that analysts predict earnings forecasts more accurately than mechanical prediction models (Givoly \& Lakonishok, 1984). The extent to which these forecasts reflect all available information, however, has not been tested.

Many studies have been performed on the usefulness of financial statements to securities analysts in making investment recommendations. Chang (1981) sent questionnaires to 1,000 securities analysts in three countriesthe United States, the United Kingdom, and New Zealand. The study concluded that financial statements are an analyst's single most valuable source of information. In addition, securities analysts determined that annual and interim financial reports, prospectuses and communications with management are essentially equal as important sources of information. They considered news reports, corporate press releases, and advisory services to be less important. The same study ranked elements of the financial statement within the annual report-income statement, balance sheet, statement of changes in financial position, accounting policies, and segment informationin order of their importance as an information source. These elements of information were determined to be useful whether the investment decision was buy, sell, or hold.

Securities analysts regularly meet with the management of the companies they follow, and their reports tend to reflect the positions of management, sometimes at the expense of their own judgment. Securities analysts, therefore, should be aware of the reliability of company management as a source of information.

One securities analyst sums up the information-seeking process by saying that he divides information into four parts - the information he knows that nobody else knows, what nobody knows, what he knows that everybody else knows, and what he does not know that everybody else knows. He says that most of his time is spent in an effort to know what everybody else knows, and the future lies in gaining the information that nobody knows (Kleinfield, $1985)$.

\section{Securities Analysts: Roles and Rankings}

\section{The Changing Role of Securities Analysts}

Investment banking firms are both users and producers of information. They are structured like a three-legged stool, with research, portfolio management, and trading each dependent upon the other two for information. Securities analysts, portfolio managers, and traders each provide advice and stock recommendations to clients based upon this information (Geyer, 1969). Almost 3,000 securities analysts work in investment banking firms preparing research reports for such large institutional clients as pension funds and insurance companies, as well as large retail clients (Lamont, 1995).

A typical research department in the United States employs a few generalists, but most of the securities analysts are specialists, often called sector analysts, who follow companies within a specific industry or sector. In some firms analysts cover more than one sector, and not all sectors are covered by every firm. The October 1995 Institutional Investor All-America Research Team survey included 76 industry categories covered by 311 securities analysts from 26 investment firms (Meisler \& Bent, $1995)$. Within any one industry or sector, the analysts or their firm select the companies that will receive coverage. In 1988 , only 7,000 of the 20,000 public companies were listed on one of the three major stock exchanges, and of these only 4,800 received research coverage (Nelson, 1989).

Prior to May 1, 1975, when the demand was for background information on industries and companies, securities analysts wrote monographic length "maintenance" research reports. Since brokerage commission rates were fixed, investment firms competed for institutional clients by making research reports available to them. Analysts 
had time to produce these extensive reports because they were not expected to advise money managers or forecast stock recommendations (Kleinfield, 1985). May 5, 1975 brought about an end to fixed commission rates for stock and bond trading in the United States, as a result of a ruling by the Securities and Exchange Commission (SEC) (Gillis, 1985, p. 16). This forced clients to bargain for the cheapest fees, and analysts to market their research to institutions in an effort to bring in trades and justify their salaries.

Today, securities analysts have fewer hours to spend on research, and the trend is to write shorter and more frequent reports. Descriptive reports containing historical data have been replaced by reports formulating profitable investment ideas. Their recommendations hold great power, representing a substantial profit, or loss, to the stockholder and to the company.

The successful securities analyst must act as an economist, an accountant, and a legal expert, as well as an industry specialist (White, 1976). Analysts must understand new accounting rules and laws in order to determine their effect on the companies and industries they follow. Securities analysts must also be versed in the disclosure requirements of securities laws and regulations.

The internationalization of business, along with the ongoing internationalization of the securities markets, has added to the information needs of securities analysts. The "Big Bang," the deregulation of London's securities markets on October 27, 1986, contributed to the internationalization by making it easier to compete in the international arena (Nicholas, Erbach, \& Paalman, 1987a). The stock exchange abolished its system of minimum commissions and introduced its new computer-assisted dealing system, Stock Exchange Automatic Quotations (SEAQ). Transactions can now be executed through this automated system which displays prices on a continuously updated basis (Rider, 1987).

New York, London, and Tokyo are the three key capital markets of the world. The movements of these three markets tend to be closely intertwined, as became evident on Black Monday, October 19, 1987. The October 1987 stock market crash caused all three markets to lose a large percent of their value. This interconnectedness and the increased activity within the capital markets has increased the need for quick and accurate information. A key element in the globalization of the financial markets is the information systems available to traders and securities analysts (Lohr, 1986). This high technology environment permits automated trading worldwide and the dissemination of financial information to securities analysts via an automated global communications network.

\section{Industry Studies and Rankings}

Several frequently cited industry studies are conducted regularly. These include the Institutional Investor AllAmerica Research Team, the Wall Street Journal All-Star
Analysts Survey, Securities Week Semi-Annual Research Survey, Nelson's Survey of Investment Research (Nelson, 1995), and Greenwich Research Associates Institutional Equity Survey. The studies rank individual securities analysts and equity research departments in investment firms (Dorfman, 1995a, 1995b).

To summarize just one of these surveys, one of the oldest and most prestigious U.S. studies is the Institutional Investor ranking, which is more often referred to as the II ranking. Within industry categories and investment specialties, individual securities analysts are rated on their performance in each of the following areas: Stock selection, earnings estimates, service and accessibility, and written reports. The team for each industry category is comprised of first, second, and third place, and runnersup. The October 1994 study ranked 444 securities analysts from 34 firms in 79 industry categories, based on 3,000 mailed questionnaires, 600 of which were outside of the United States (Meisler \& Bent, 1994). The earnings estimates of the Institutional Investor All-American Research Teams outperformed the average analyst (summarized in Dorfman, 1994b, 1994c). These surveys also report on many other industry topics. For example, the Securities Week semi-annual survey also reports on trends in industries studied, related industry factors, and compensation (Lamont, 1995).

There are several other significant annual surveys that rank U.K. and European securities analysts on their research. They are the All-Europe Research Team, the Extel Financial Survey of Investment Analysts, the MORI Financial Research Poll, and the Euromoney European Brokers Survey (Extel Financial, 1993; Market \& Opinion Research International, 1990; Meisler \& Bent, 1992, 1994, 1995; Moore, 1992).

These surveys are significant for several reasons. Surveys and rankings are used by the financial community to measure the outcomes discussed in this study. They measure the income and ranking of securities analysts, and to some extent their productivity and satisfaction. These surveys are also widely used as benchmarks that determine the compensation of ranked analysts. Receiving a high ranking in the All-America Research Team survey, for instance, can add $\$ 100,000$ or more to an analyst's market value (Dorfman, 1994a). Analysts with the right credentials - those who cover a "hot" industry, or are ranked in the Institutional Investor's All-America Research Team-are always paid top dollar regardless of the prevailing economic conditions (Wipperfurth, 1995).

But there is more to measuring the worth of securities analysts than keeping track of their recommendations and their outcomes. Firms also measure analysts' performance by: Their ability to produce high quality research and dependable reports; their ability to market their research through phone calls and visits to clients; their understanding of the investment process; their ability to come up with good investment ideas; their ability to cope with adversity; the reputation they have acquired among cli- 
ents, competitors, and associates; and their ability to keep on top of the situations they have recommended (Mattlin, 1969).

In 1995, analysts were still in demand and well compensated, but the economic downturn on Wall Street forced investment firms to stop expanding their research departments. It is, therefore, even more crucial for analysts to have their track record measured against their peers, and to be recognized for their achievements. Since the top analysts are recognized for the accuracy of their stock picking and earnings estimates, their research brings in business for the firm. Investment firms are interested in analysts who are ranked in surveys because they have name recognition and can bring in money for the firm. Good research reports lead to good investment decisions. These analysts can generate ideas for deals. Investment firms are often hired to lead or co-manage a deal on the strength of their research coverage. On the other hand, investment firms have been left out of stock offerings because of poor or no research coverage of a company. Also important is the trading volume the firm does in the stocks the analyst covers. Firms rely on the contacts securities analysts have made to direct a large volume of institutional trading to the firm.

\section{Model and Hypotheses}

Figure 1 presents the model of the proposed relationships among individual, institutional, source/channel, and outcome variables, as summarized in five general hypotheses. In addition to the general prior research on user information needs, the following sections refer to specific individual, institutional, and information/communication influences.

Invisible colleges exist among workers in business and industry as well as in academia. Campbell (1975) found that businessmen consider the "old boy network" to be a valuable source of information, one which continues to exist within the securities industry and influence the way securities analysts gather information. Men have the advantage of using the informal contacts they have acquired over the years, within a specific industry, to obtain information. A study by Advertising Women of New York shows that $65 \%$ of the women respondents believe the " old boy network" continues to exist, particularly at ad agencies (Danzig \& Wells, 1993 ).

Aguilar (1967), Allen (1977), and Rosenbloom and Wolek (1967, 1970) found that experience is a significant influence on the information/communication channels used by scientists and technologists. The working habits of securities analysts also seem to confirm this hypothesis. When analysts begin coverage of a new company, they spend a lot of time obtaining historical information from the library. But as their coverage of the company or industry continues, they have less need for background-type information. They de- pend on the data analysis and current statistics they obtain from their own computerized resources. In turn, the time required to perform this research increases the amount of hours they work.

\section{Individual Characteristics of Securities Analysts Influence Their Use of Information Sources and Communication Channels}

Greater age and experience lead to greater computer usage.

Male analysts have greater access to informal information and external contacts than do female analysts.

Analysts who are members of professional associations have greater access to informal information and external contacts.

As their experience increases, securities analysts' use of library resources decreases.

Securities analysts who work longer hours make greater use of media and computer resources.

It seems likely that the environment in which securities analysts work influences their internal and external communication channels over and above, and possibly more powerfully than, the individual influences. The securities analysts who work in investment firms of varying size and prestige have access to different staff and resources to assist them in acquiring information and writing research reports. They also have different budgetary support for conferences, meetings, and visits to the companies they cover, and use of printed and computerized resources. Similarly, it also seems likely that securities analysts who attend more annual meetings and trade shows have greater access to contacts outside of their firm. These meetings also present the analysts with an opportunity to exchange information with these contacts on an informal basis.

Securities analysts who work in regional firms are more likely than full-service firm analysts to cover companies that are located in their local community. Therefore, it would seem likely that regional firm analysts find their local newspapers to be a valuable source of information.

Analysts acquire information from external sources and disseminate information to others within their firm. Sometimes they need to interpret the information prior to its dissemination. Individuals within the firm, most noticeably traders and investment bankers, are dependent on this information to perform their jobs. Securities analysts also interpret and distribute this information to institutional and retail clients of the firm. While the literature states the importance of individual characteristics on the use of information sources and communication channels, the institutional resources provide the basic context that allows people to do things, so we would expect that the institutional resources available to securities analysts influence their use of external information/communication channels and, in doing so, their role as gatekeeper. 


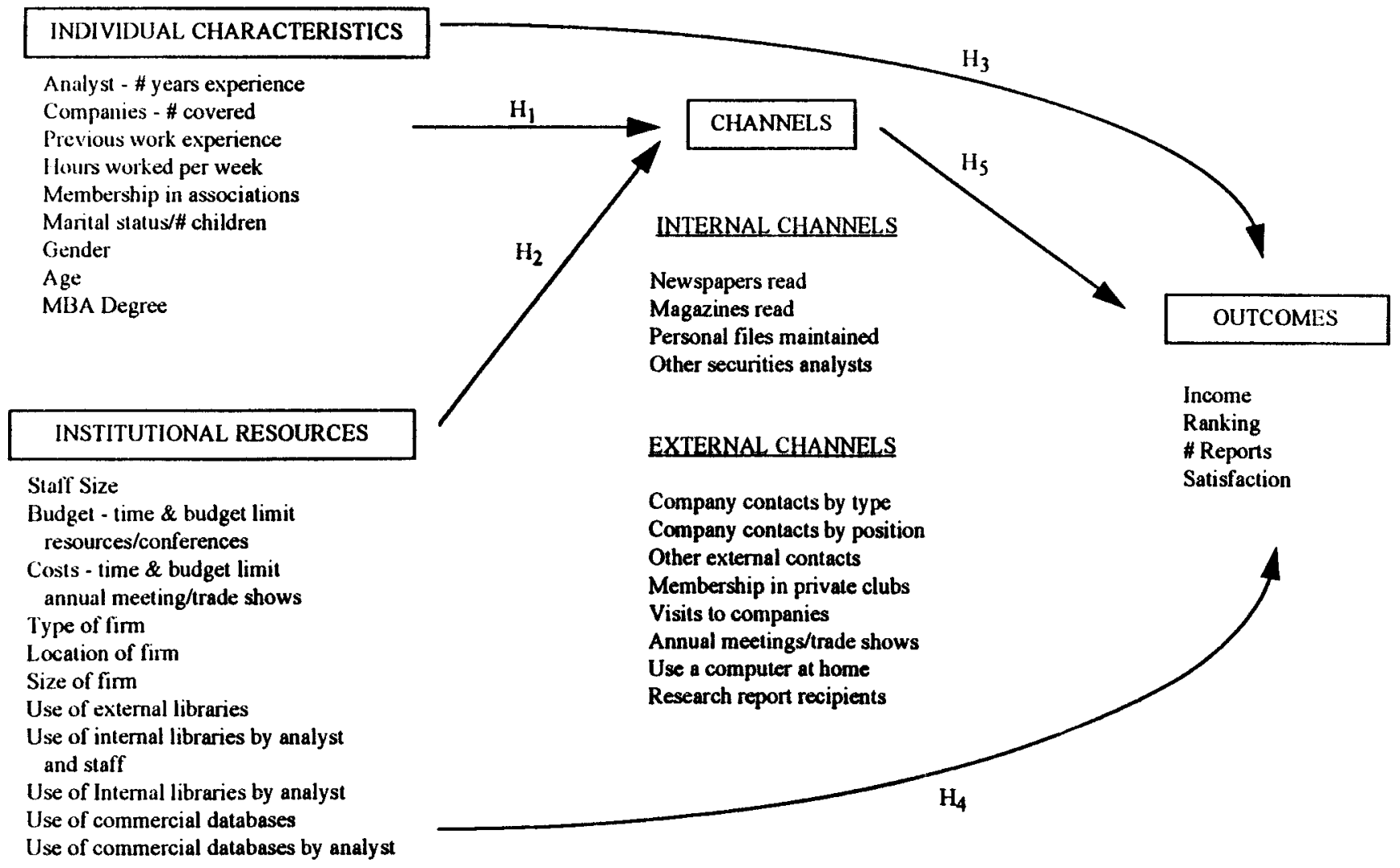

FIG. 1. Proposed theoretical model involving individual characteristics, institutional resources, information sources and communication channels, and outcomes of securities analysts.

\section{Institutional Resources Lead to Greater Use of Information Sources and Communication Channels by Securities Analysts}

Greater staff and budget lead to greater use of printed resources and computerized databases.

Greater support for attendance at annual meetings and trade shows leads to greater use of external contacts and informal information.

Securities analysts in regional firms make greater use of local newspapers than analysts in full-service firms.

Analysts depend on personal contacts as a source of information to a greater extent than on media and computer resources.

Demographic variables of user groups have received much attention in previous user studies. In particular, gender studies indicate that women in many male dominated professions are more likely to be passed over for promotion and receive less recognition and lower pay than their male counterparts (Cannings, 1988; Danzig \& Wells, 1993; Uchitelle, 1993). Although the number of female securities analysts has grown in the past decade, women still only make up about $19 \%$ of all analysts, and about $15 \%$ of the analysts named to the All America Research Team (Lewis, 1989). Even though these studies show that female executives do experience lower salaries and fewer promotions, it seems likely that productivity and satisfaction are not gender-specific.
Age and education are demographic variables that seem likely to influence analysts' outcomes. Older workers are more likely to stay at their job for a longer period of time than younger workers, and are as productive, if not more so, than younger workers (Dychtwald, 1990). Studies reviewed by and conducted by Muchinsky (1978) and Rhodes (1983) show that older workers are more satisfied with their jobs and more committed to their firms than younger workers. Many of these studies focus on workers in large firms, but a study of older workers in small businesses found that age is also positively correlated with job satisfaction (Smith \& Hoy, 1992).

Employees who hold M.B.A.s or Ph.D.s experience greater income (Jones, 1990) and place greater emphasis on job satisfaction than on financial success (Berney, 1990). It seems that membership in professional associations is an indication of professional interest and leads to higher productivity and satisfaction. It also provides an entree to contacts who can promote analysts in the rankings. Ranking and other forms of professional visibility such as membership in professional associations appear to lead to greater income (Nudell, 1992).

Another likely influence on outcomes, though not necessarily as one might expect, is the amount of time workers spend at their job. One study found that although managers are working more hours, it does not necessarily mean achieving greater productivity, because increased 
exhaustion decreases creativity and analytic abilities (Fisher, 1992). However, another study showed that the number of hours worked is positively associated with income (Bretz, 1989). Although nothing was found in the literature to support this, it also seems logical that analysts who work longer hours have more external contacts. And although these contacts help analysts receive recognition and ranking, the long hours may eventually result in job dissatisfaction.

\section{Individual Characteristics of Securities Analysts Influence the Outcomes of Their Information Activities}

Female analysts have lower incomes and rankings than male analysts, but gender has no association with productivity and satisfaction.

Age is positively associated with income, ranking, productivity, and satisfaction.

Securities analysts who have an MBA have a higher income and ranking, and experience greater productivity and satisfaction than those who do not have an M.B.A.

Securities analysts who are members of professional associations experience greater productivity, satisfaction, income, and ranking.

The number of hours analysts work is positively associated with income and ranking, but is negatively associated with productivity and satisfaction.

Greater job experience leads to higher income, ranking, productivity, and satisfaction.

It has been documented, particularly in scientific and academic communities, that people who attend or work at prestigious and moneyed institutions have an advantage over those who are associated with other institutions. For example, a recent study concluded that although age and experience of plant engineers are highly correlated with income, the size of the company is the main factor in determining income (Dunn, 1993). This advantage for those in university settings comes about partly as a result of their association with professors and scientists who have established reputations and connections, and their access to superior laboratories and libraries. Merton (1968) named this phenomenon the Matthew Effect, after Matthew 13:12: "For unto every one that hath shall be given, and he shall have abundance: But from him that hath not shall be taken away even that which he hath." Additional studies depict how the Matthew Effect, or the " principle of cumulative advantage,', works within institutions (Cartter, 1966).

The Matthew principle also explains the influence that resources in investment firms have on the ranking, productivity, and income of securities analysts. Securities analysts who work in information-rich firms have heightened visibility, stand a better chance of being ranked, and receive higher pay as their research is more widely distributed.

An exception to the theory that greater institutional resources lead to greater outcomes is the use of internal libraries. Findings of previous research indicate that library usage by various professional groups is low, and that the use of libraries does not influence their work (Ford, 1973; Friedlander, 1973; Nicholas, Erbach, \& Paalman, 1987b).

Greater Institutional Resources (Staff and Budget Size; Attendance at Meetings, Trade Shows, and Conferences; Computer Usage; and Working in FullService Firms) Lead to More Positive Outcomes. However, Type of Firm Has No Association with Satisfaction, and Use of Libraries Has No Association with More Positive Outcomes

Securities analysts who are ranked have an extensive following, and therefore have a greater chance for their research to be read by clients and other analysts. The research reports of securities analysts are often selected on the same basis as that of significant and productive scientists.

\section{Use of Information Sources and Communication Channels Leads to More Positive Outcomes}

Greater use of informal channels, external contacts, and computer usage leads to greater productivity, satisfaction, income, and ranking.

Greater marketing and dissemination of research reports leads to greater income and ranking, but lower productivity and satisfaction.

\section{Method}

The investment banking firms included in the study were selected from the 1990 Institutional Investor list of the largest U.S. investment firms ranked by consolidated capital (Bent \& Halliday, 1990). The names of the securities analysts working in the equity research departments of the selected firms were obtained from the 1990 edition of Nelson's Directory of Investment Research. The analysts were stratified by type of firm: Regional, full-service, and foreign firms. A total of 1,084 securities analysts worked in the top 40 investment firms ranked in the study. Within these 40 firms, the top 13 full-service firms (excluding the one for which the first author was employed) had a total population of 743 analysts, and the top 27 regional firms had a total population of 341 analysts. Three random number tables, one for each of the reports, were generated to select a final overall total of 100 securities analysts to be interviewed (i.e., taking into account nonparticipants, discussed below). Thus the final sample is comprised of 50 domestic full-service analysts, 20 foreign full-service analysts, and 30 regional analysts, each proportional to the type of analysts in the whole population.

A questionnaire was developed with the assistance of five securities analysts in the Research Department of the investment banking firm for which the first author was 
working and pretested by another five analysts in the Department.

Telephone interviews were conducted with the securities analysts selected by the random number tables. If the analyst decided not to participate in the study, the telephone call was terminated and the next number on the random number table was used to choose another analyst. A total of 166 analysts who were contacted did not participate in the study, with reasons consisting of being too busy, did not want to participate, had left the firm (34), or could not be reached after several attempts (86). Of the 46 analysts who declined to participate in the study, 38 were from domestic full-service firms, four were from foreign firms, and another four were regional firm analysts. Most of these 46 analysts said it was a busy time for them, but they would be happy to be interviewed in a few weeks. Additional attempts to contact these analysts were unsuccessful.

The consent agreement was read to each analyst who agreed to participate in the study, and the interviews were tape recorded. The interview tapes were transcribed and coded. The coded data was entered into a system file. The proposed relationships among the quantitative variables were tested using bivariate correlation and multivariate canonical correlation analysis.

\section{Results}

\section{Descriptive Statistics with Comments}

Table 1 provides descriptive statistics on the variables. Relevant comments from the analysts for some of the questions follow.

Of the 37 analysts who responded that former employment in the industry influences the way they obtain information in their present position, $50 \%$ responded that it influences their thinking. One of these stated that it gives him a feel for how the real world works. Another said that it makes him more cynical than other analysts. One of the analysts responded that although previous industry experience has no influence on the way he currently obtains information, it influences what he does with the information once he has it. Another replied that although it has no influence on the way he obtains information, it makes him aware of the information he does not need to look at, because it is not important to the business. Approximately another $15 \%$ responded that their prior experience in the industry provides them with a network of personal contacts which they now use to obtain information.

Of those analysts who responded, 34\% said that they do not want to read competitors' research reports. Many analysts feel this is a sensitive question. They are afraid that if they admit to reading their competitor's research, they will be accused of copying their work. It is also the consensus of these analysts that they do not want to have their judgment clouded by what someone else is saying.
On the other hand, one regional firm analyst commented that he likes to read competitor's research, as often as possible, because the more you know of what the competition knows, the better off you are. A domestic full-service firm analyst responded that there is a benefit to reading competitors' research, as it improves your understanding of how people in the investment community look at the company or industry in question, and that it is just another check you can use on your own analysis. Those analysts who responded were almost evenly divided as to the difficulty of obtaining competitors' research. Twenty-four percent responded that it is difficult, $23 \%$ felt it is not difficult, while $53 \%$ said this question was too sensitive to answer. Several of the regional firm analysts said they belong to a round table of regional firms and are allowed to obtain reports written by analysts who work for those firms.

Just over half responded that there are no budgetary restrictions on journal and database usage. More analysts in foreign firms and domestic regional firms have limited journal and database usage, due to budgetary constraints, than do domestic full-service firm analysts. These analysts said that subscriptions have been cut back and that it is a battle to get any kind of electronic data. A domestic full-service firm analyst summed it up when he said that when the market is hot and things are good, you buy a lot more and when the market is not so hot and things are not so good, you buy a lot less.

Just over three-quarters of the analysts, especially those in domestic full-service firms, responded that they or their staff use commercial databases. Several of the analysts commented on the problems they have with commercial databases. One domestic full-service firm analyst said that the databases contain a lot of errors and the information is old; instead, he receives earnings information faxed directly from the companies. Another domestic full-service firm analyst said he receives corporate news and press releases by E-mail and messenger. A regional firm analyst said, "With data bases, the problem is not so much that the information isn't there, the problem is how to define it narrowly enough so that you get exactly what you need.',

Nearly two-thirds responded that they find analyst meetings to be valuable, and $18 \%$ responded that they are extremely valuable. One foreign firm analyst, who was among those who find them valuable said, "The companies are normally prepared to give out more information at an analyst meeting than at any other time.' It seems to be the consensus that one has to go to analyst meetings because all one's competitors go and in the event something important is said, "You don't want to miss it.' Several analysts also responded that it is helpful to hear the questions the other analysts ask during the Q\&A period, as they might be things that you have not thought of. A third benefit is seeing how management gets along and how they treat each other.

Half of the analysts responded that they obtain valuable 
Work related background

Years worked as a securities analyst.

$332-5 ; 376-10 ; 911-15 ; 1216-20 ; 7$ More than 20

Years worked as a securities analyst at your present firm.

31 year or less; $652-5 ; 22$ 6-10; 9 11-15

Industries currently followed.

25 Financial services; 3 Defense; 8 Health; 13 Technology; 6 Transportation; 12 Natural Resources; 3 Media; 6 Generalist-European; 17

Manufacturing products; 1 Real Estate; 2 Utilities; 4 Pollution control

Covered any other industries while working either at your current firm or at previous firms? $58 \mathrm{Y}$

Number of companies covered.

4 Less than 10 companies; 42 10-15; 26 16-20; 20 21-30; 6 More than 20

Ever been employed in any of the industries and/or companies you have followed as a securities analyst? $37 \mathrm{Y}$

Has previous employment in the industries and/or companies you have followed as a securities analyst influenced the way you obtain information in your present position? $22 \mathrm{Y} \quad 12 \mathrm{~N}$

How has previous work experience in the industries and/or companies you have followed influenced the way you obtain information in your present position?

12 No influence; 17 Influenced thinking; 5 Network of personal contacts

What was your job immediately before you became a securities analyst?

41 Student; 23 Worked in another capacity in industry now following; 14 Worked in another capacity in securities industry; 21 Other

What is your current position/job title?

66 Vice President; 1 President; 5 Managing Director; 8 Director of Research; 20 No title (Equity Analyst)

Are you an officer of your firm?

$80 \mathrm{Y}$

Sources of information-print

Do you read any of the following newspapers, everyday, for general business new and information?

Financial Times: 40 Y; The New York Times: 64 Y; Wall Street Journal: 92 Y; London Times: 7 Y; Investor's Daily: 20 Y; Barron's: 25 Y; Other $16 \mathrm{Y}$

Do you read any of the following periodicals, on a regular basis, for general business news and information?

The Economist: 29 Y; Institutional Investor: 17 Y; Business Week: 58 Y; Forbes: 39 Y, Fortune: 31 Y

How often do you obtain research reports written by other investment firms?

55 Occasionally, sometimes; 13 Regularly; 32 Never

Do you obtain research reports written by other investment firms?

$32 \mathrm{Y}$

Do you want to obtain research reports written by other investment firms?

$32 \mathrm{Y} \quad 34 \mathrm{~N}$

Is it too difficult to obtain research reports written by other investment firms?

$24 \mathrm{Y} \quad 23 \mathrm{~N}$

What kind of personal files do you maintain?

SEC filings: 85 Y; Notes from telephone conversation, company visits: 45 Y; Press releases: 61 Y; Newspaper, journal clippings: 49 Y;

Company presentations, product literature: $33 \mathrm{Y}$

How often do you consult your personal files?

75 Daily; 16 1-2 times a week; $31-2$ times a month; 5 Other

How often do you mail questionnaires to the companies you are covering?

19 Occasionally; 4 Frequently; 77 Never

Do you mail questionnaires to the companies you are covering?

$23 \mathrm{Y}$

Sources of information-computerized

Do you use a personal computer...

At work: 96 Y $4 \mathrm{~N}$; At home: 63 Y $35 \mathrm{~N}$

Do you, or your staff, use any computer-driven quantitative tools or models when doing research on a company or industry? $96 \mathrm{Y}$

Who uses these models?

You: 93 Y 3 N; Research Assistant; 41 Y 15 N; Secretary: 13 Y 58 N

Do you, or your staff, use any commercial data bases when researching a company or industry? 74 Y $22 \mathrm{~N}$

If yes, do you, or your staff, use any of the following commercial data bases when researching a company or industry? Textline: 7 Y 71 N; Data Stream: 7 Y 71 N; Nexis: 17 Y 57 N; Others: 66 Y 8 N 
Sources of information-computerized

Who searches the commercial data bases?

You: 54 Y 24 N; Research Assistant: 36 Y 12 N; Secretary: 5 Y 53 N; Library Staff: 19 Y 51 N

Have you seen any changes in your information seeking patterns as a result of computers?

49 Yes; 31 Always used a computer; 1 Never use a computer; 19 No

Is there any information pertinent to your research that you would like to see computerized? 55 Y $42 \mathrm{~N}$

Channels of communication

With whom in your firm (position) do you most frequently exchange information about a company or industry?

73 Salesforce; 16 Other analysts; 9 Brokers/Traders

Do you sit in a formal meeting, on a regular basis, to exchange information with anyone in your firm? $92 \mathrm{Y}$

If yes, who within your firm attends these meetings? 92 Salesforce; 8 Other

Are you ever called upon to help other securities analysts within your firm write reports or gather information?

61 Occasionally, sometimes; 4 Frequently; 34 Never, infrequently

Are you ever called upon to help other securities analysts within your firm write reports or gather information? $65 \mathrm{Y}$

Library usage

Does your firm have a library?

$93 \mathrm{Y}$

How often do you or your staff use your firm's library for research?

7 Never; 13 Less than once a month; 20 1-2 times a month; 41 1-2 times a week; 9 Daily

Who searches your firm's library?

You: 61 Y 32 N; Secretary: 10 Y 60 N; Research Assistant: 33 Y 21 N; Library Staff: 66 Y 21 N

Do you use other libraries for research?

37 Y 63 N; Public libraries: 19 Y 18 N; University libraries: 11 Y 26 N; Trade assoc. libraries: 10 Y 27 N

Staff and budget

What kind of support staff do you have?

Secretary: 73 Y 26 N; Research assistant: 55 Y 43 N

Does cost or department budget size affect the way you currently go about obtaining information and the sources you use? $47 \mathrm{Y}$

Do budgetary restrictions limit your ability to travel and attend conferences?

19 Y $73 \mathrm{~N}$

Research reports

What is the average amount of time you spend writing a research report?

11 Less than 1 day; 38 1-7 days; 15 2-4 weeks; 1 More than 1 month; 35 Varies greatly

Does that time differ when you are writing about a new company versus a company you are already covering? $100 \mathrm{Y}$

Who within your company (position) receives a copy of your report?

100 Salesforce/Brokers

Do you send your reports to:

Institutional clients? $100 \mathrm{Y}$; Retail clients? 80 Y $20 \mathrm{~N}$; The companies? $94 \mathrm{Y}$; The press/news media? $70 \mathrm{Y} 18 \mathrm{~N}$

Have your written reports changed in terms of thoroughness, length, and time devoted to them during the past few years?

53 Tend to be shorter; 10 Tend to be longer; 7 Varies with report; 2 Others; 28 No change

Do you rely on the Editorial Department in the writing of your reports? 83 Y $9 \mathrm{~N}$

Do you rely on the Compliance Department in the writing of your reports? 100 Yes

How many reports do you publish a month, on average?

3 Less than 1 report; 54 1-5 reports; 20 6-10 reports; 4 11-15 reports; 7 More than 15 reports; 12 Can not quantify

How has the ratio of time you spend on marketing versus the time you spend on primary research changed over the past few years? 38 More time on marketing; 14 More time on research; $19 \mathrm{~N}$ change

Has the ratio of time you spend on marketing versus the time you spend on primary research changed over the past few years? 52 Y $19 \mathrm{~N}$ 
Research reports

How has the marketing versus research change influenced the coverage of the companies you follow?

8 Work longer and harder; 14 Produce shorter and less frequent reports; 1 Research has benefited; $34 \mathrm{~N}$ effect

Do you ever employ industry experts to consult with you? $42 \mathrm{Y}$

Are you ever called upon by securities analysts outside your firm (other sell-side analysts) for information? 30 Occasionally, yes; 69 Never, infrequently

Do you sit, in a formal way, on any boards or hold any meetings outside your firm to exchange information about a company or industry? $38 \mathrm{Y}$

As you continue to cover an industry or company how often, if ever, do you visit that company?

68 Once a Year; 18 Twice a year; 8 More than twice a year; 4 Less than once a year

Whom to you speak to within the company?

CEO, President, Chairman: 77 Y 21 N; CFO, Treasurer: 88 Y 10 N; Investor relations contact: 51 Y 43 N; Division/dept. heads: 33 Y 60 N

What percentage of companies allows you to speak with operating personnel?

49 90-100\%; $1750-89 \% ; 311-49 \% ; 90-10 \%$; 10 Did not quantify by percentage

What is the reliability of the information obtained from operating personnel?

9 Excellent; 58 Fair, good, average; 3 Poor; 18 Varies, can't quantify

What percentage of companies allow you to speak with senior corporate management?

84 90-100\%; $1050-89 \% ; 111-49 \%$; 5 Did not quantify by percentage

What kind of information do you obtain from senior corporate management?

60 Strategic; 13 Other

What is the reliability of the information obtained from senior corporate management?

9 Excellent; 76 Fair, good, average; 2 Poor; 13 Varies, can't quantify

How many of the companies that you follow hold analyst meetings?

44 90-100\%; 29 50-89\%; $1911-49 \%$; 7 Did not quantify by percentage

What is the value of attending the analyst meetings?

59 Valuable; 17 Extremely valuable; 11 Value varies; 10 Limited to no value

Approximately how many days each year do you spend in annual meetings and trade shows?

35 1-5 days; 16 6-10 days; 16 11-20 days; $821-30$ days; 6 More than 30 days; $19 \mathrm{~N}$ days

What is the value of the information you obtain from annual meetings?

14 Valuable; 15 Value varies; 48 Limited to no value

What is the value of the information you obtain from trade shows?

48 Valuable; 12 Value varies; 20 Limited to no value

Does cost play a factor in the number of annual meetings and trade shows you attend?

26 Y $52 \mathrm{~N}$

Does time play a factor in the number of annual meetings and trade shows you attend? 51 Y $27 \mathrm{~N}$

To what degree do you depend on the "informal" exchange of information?

85 High degree; 13 Low degree

Do you have any mechanism or routine you use to check the reliability of this "informal" exchange of information?

70 Cross check the reliability with other sources; 21 Don't check it

Are you a member of any private club or country club?

$31 \mathrm{Y}$

Do you talk business at the clubs?

$13 \mathrm{Y} \quad 18 \mathrm{~N}$

Has the marketing versus research change influenced the coverage of the companies you follow? $23 \mathrm{Y} \quad 34 \mathrm{~N}$

How satisfied are you with the amount of information and research you are able to accumulate before you give advice or write reports for your clients or firms?

72 Satisfied; 14 Sometimes satisfied; 13 Frequently not satisfied

Personal background

Age.

25 25-30; 21 31-35; 20 36-40; $1741-45 ; 1046-50 ; 4$ 51-55; 1 56-60; $161-65 ; 1$ Older than 65

Marital status.

69 Married; 30 Single

Children?

$49 \mathrm{Y} \quad 47 \mathrm{~N}$

Sex.

68 Male; 32 Female

Education.

Undergraduate: 95 Y; Graduate: 75 Y; MBA: 59 Y; Ivy League degree: 38 Y 
Personal background

Into which of the following categories does your income level fall?

Regional firms:

1 Less than $\$ 50,000 ; 3 \$ 50,000-74,999 ; 4 \$ 75,000-99,999 ; 6 \$ 100,000-149,999 ; 8 \$ 150,000-200,000 ; 2$ More than $\$ 200,000$;

Full service firms:

5 Less than $\$ 100,000 ; 4 \$ 100,000-149,999 ; 5 \$ 150,000-199,999 ; 1 \$ 200,000-249,999 ; 4 \$ 250,000-300,000 ; 14$ More than $\$ 300,000$

Foreign firms:

0 Less than 50,000 pounds; 1 50,000-74,999 pounds; 5 75,000-99,9999 pounds; 2 100,000-149,999 pounds; 2 More than 150,000 pounds

Hours worked per week.

1 Less than 40; 19 40-50; 49 51-60; 20 61-70; 9 71-80; 1 More than 80

Are you a member of the Association of Investment Management and Research?

$35 \mathrm{Y}$

Are you a member of your local society of security analysts?

$40 \mathrm{Y}$

Are you a member of a splinter group of your local society?

$39 \mathrm{Y}$

Are you currently ranked in the Institutional Investor All-American Research Team Survey? (Domestic Firm Analysts only)

$22 \mathrm{Y} 28 \mathrm{~N}$

Are you currently ranked in the Extel Survey? (Foreign Firm Analysts only)

$10 \mathrm{Y} \quad 7 \mathrm{~N}$

Type of firm.

70 Full Service; 30 Regional

Location of firm.

80 Domestic; 20 Foreign

Size of firm (\$million).

13 Less than 50.0; 10 50.0-99.0; 9 100.0-499.0; 26 500.0-3,999.0; 42 More than 4,000.0

"Missing," " "not applicable," or categories for which there were no responses, are not included. $\mathrm{N}=100$, so only number of "'Yes" responses listed, except for questions that are result of a prior filter question. Values are frequencies and category label.

information from trade shows. They also find trade shows a good place to network, gossip, and develop industry contacts. It is also a good place to talk to competitors and see how users are responding to a company's products. One foreign firm analyst said, "I use the trade shows to understand what is going on around the company. Very often, you can see a line of new products, or you can see trends developing that the company's a part of, or not a part of. It is quite important to know what the trend of the industry is and whether the company's deviating from the trend.'

Two-thirds responded that time is a major factor in the number of annual meetings and trade shows they attend. As one regional firm analyst said, "Maybe you could use the word opportunity - opportunity cost is more valuable than financial cost. Distance plays a big factor. It is a lot easier for me to go to meetings and trade shows that are closer or more enjoyable.'

Most of the domestic analysts replied that they get most of their information informally, that they depend almost entirely on informal information and that the informal part is probably the most important part. One foreign analyst said, "If it is not the predominant source of information, it is probably the most lucrative source of information." And another offered that "The best way to describe informal information is as the icing on the cake." One analyst commented, "I would say that's [informal information] probably more than half your daily flow." Another noted, "That's [informal information] probably as much, or more, of the thing than anything else." Still another analyst said, "I don't get a lot of my information on an informal basis, but I get my most important information on an informal basis."

Just over three-quarters responded that they check on the reliability of the information they obtain informally. The analysts tend to use two basic methods: One method is to check it formally with someone at the company, and the other is to confirm it with several different independent sources, such as their customers and competitors. One analyst said, "If you have been an analyst long enough, you pick up bits and pieces and almost intuitively know what is right and what is wrong. There are some people who perhaps elaborate too much, and they are considered promotional. You can regard that kind of information with skepticism. But I think that it is experience that gives you the ability to be able to judge that. Some people have a natural ability to do it, but I had to learn it."

Eighty percent of the analysts responded that they send copies of their research reports to the news media. One domestic full-service firm analyst made the following comment, "Analysts have a good reason to send their reports to the news media, because it helps enhance the distribution of the report and also creates media awareness that the analyst exists. There is an individual ego involved in this whole approach."

Half indicated that they are writing shorter reports, while $10 \%$ indicated that they are writing longer reports. The analysts seemed to be all across the board in their responses to this question. One reason for this is that the 
trend seems to move back and forth. Another reason is that many of the analysts responded that they write long and short pieces, depending upon the company and the situation. One domestic full-service firm analyst said, "There is probably more pressure from the industry to write shorter reports. It is often said institutional investors will not read long reports. But when they are going to buy a stock, they want to know there is a long report they can refer to. So you have to have a mixture of both.', Another analyst said that they are producing shorter dayto-day pieces, which they fax or E-mail to their clients.

Just over half of the analysts responded that they are spending more time marketing their research. A foreign firm analyst summed up the situation when he said, "If you are spending more time marketing, you are obviously spending less time keeping in touch with your companies and your industry.',

Almost three-quarters said that they are satisfied with their research. As one said, "I always want more information. No matter how much [information] I get, I always want more. That is part of the nature of being an analyst.', Another said that you have to balance the amount of information with giving a timely recommendation. "You always have timeliness versus getting everything. By the time you get every single little thing, the stock price has already moved, so it is of no value.' The most frequent source of dissatisfaction seems to be management's failure to disclose enough information about the company.

\section{Bivariate Relationships}

Bivariate relationships were tested to see if statistically significant correlations exist among the variables in each of the four components of the model, as shown in Table 2. Because of space limitations, we do not discuss these correlational results. These bivariate relations can exaggerate the cross component relationships, because variables within independent sets or within dependent sets are usually correlated with each other, so that multiple bivariate correlations are not independent. Therefore, canonical correlation analysis is used to analyze these cross component or multivariate relationships. Only those variables that were statistically significant in the bivariate correlations were included in the canonical analysis.

\section{Canonical Correlation Relationships}

Canonical correlation analysis attempts to find the strongest correlations between two sets of variables. A linear combination of variables or a canonical variate is drawn from each set that maximizes the canonical correlation between the two sets. The variable's loading on the variate shows how much each variable contributes to the variate. The variable's loading on the variate is called a standardized structure coefficient. Several canonical correlations may exist as a result of several linear combinations of variables within each set, and each correlation is tested for statistical significance. A partial canonical correlation tests whether there is a direct influence between two canonical variates controlling for the influence of a third intervening variate. Tables $3 \mathrm{~A}, \mathrm{~B}$ and 4 portray the following canonical correlation results.

Influences of Individual Characteristics and Institutional Resources on Information Sources and Communication Channels. There are two significant canonical correlations among individual characteristics and institutional resources, with information sources and communication channels, explaining 58 and $46 \%$ of the variance, respectively.

The first individual characteristics and institutional resources variate is characterized by the influence cost and time play on the number of annual meetings and trade shows analysts attend, and the infrequent use analysts make of their internal libraries (variate loadings of .73 and -.39 ).

The second individual characteristics and institutional resources variate is characterized by the influence of fewer years of experience (variate loading of -.34), membership in associations (.35), greater staffing (.60), type of firm $(-.75$; a negative number means that it is a regional firm), and size of firm (.61).

The first information/communication channel variate is characterized by analysts' frequent communication with executives within the companies they covered (variate loading of .30), and low attendance record at annual meetings and trade shows $(-.90)$. And the second information/communication channel variate is characterized by the high number of newspapers analysts read (.52), their frequent talks and meetings with company executives including the president, CEO, chairman, CFO, treasurer, investor relations contact, and division and department heads (.48), and their frequent contact with industry experts, securities analysts from other firms, and attendance at meetings outside the firm (.45).

Overall, individual influences have little significant canonical influence on the use of information/communication channels. The first canonical correlation shows that analysts who make little use of their internal libraries, and who are influenced by cost and time restrictions, tend to communicate more frequently with company executives and attend fewer annual meetings and trade shows. The second canonical correlation shows that analysts who have less experience, are members of analyst associations, have a support staff, and work for large regional firms, tend to read more newspapers, communicate more frequently with company executives, and make greater use of external contacts.

Direct influences of individual characteristics and institutional resources on outcomes, controlling for influence of information sources and communication channels. A partial canonical correlation analysis tested whether there is any direct influence of the individual characteris- 
tics and institutional resources variables on the outcome variables, independent of and controlling for the intervening information/communication channel variables.

The partial canonical correlation is significant, explaining $40 \%$ of the variance. The individual characteristics and institutional resources variate is characterized by years of experience (variate loading of .59), staffing (.34), type of firm (.49; a positive number means that it is a full-service firm), and infrequent use of internal libraries $(-.34)$. The outcome variate is characterized by ranking (.78), and number of published reports $(-.37)$.

Overall, the partial canonical analysis shows that analysts who are experienced, work for full-service firms, have access to a staff, and made infrequent use of their internal libraries (individual characteristics and institutional resources variates), tend to publish fewer research reports, and are more likely to be ranked (outcome variates) independent of the intervening influence (if any) of the use of communication channels and information sources.

Influences of information sources and communication channels on outcomes. The canonical correlation between information/communication channels and outcomes is not significant, although it explains $20 \%$ of the variance. The information/communication channels variate is characterized by the influence of frequent external communication with company executives (variate loading of .82), and the infrequent use of personal files (-.57) on ranking and productivity. The outcome variate is characterized by analysts who are ranked in the polls (.94), and who publish a large number of research reports (.43).

\section{Discussion}

\section{Summary of Results}

Some statistically significant correlations occurred among the variables in each of the hypotheses. The results show that individual characteristics have little influence on the information source and communication channels used by securities analysts, and thereby do not have a significant indirect or direct influence (except for years worked as an analyst) on the outcomes of analysts' information activities. This finding rejects the first underlying argument found in information science literature, concerning the importance of individual characteristics. On the other hand, the results show that institutional resources do have a significant influence on the information source and communication channels analysts use, and thus both an indirect and direct positive influence on some of the analysts' outcomes. This finding supports the second underlying argument, concerning the importance of institutional resources.

\section{Implications for Corporate Librarians}

"What the managers need are the value-added services of screening, summarizing, synthesizing, highlighting, and presenting information in a useful and timely manner" (Katzer \& Fletcher, 1992, p. 251). Thus, overall, information support staff should focus on resolving problematic situations instead of retrieving information and answering questions. This implies a strong need for interaction over time to define organizational situations.

Librarians can make information on CD-ROMs, commercial on-line databases, and in-house databases available to analysts and other users via LANs (Local Area Networks) and WANs (Wide Area Networks). Since analysts work long hours, travel extensively to visit companies, and attend meetings and conferences, they need to be able to access information while at home and traveling. In the interviews, the securities analysts indicated that they depend heavily upon the filings that public corporations are required to make to the Securities and Exchange Commission. Since 1993, corporations have been filing these documents electronically via the EDGAR (Electronic Data Gathering, Analysis, and Retrieval) system. Several commercial information systems, including LIVEDGAR and Federal Filings, now make these documents available within minutes after they have been filed. The Internet also provides access to SEC documents, but at a considerable time delay. These are examples of systems which the information professional should be making available and training securities analysts to access from their desk tops.

In making information available to the end-user, librarians can also make their own jobs more important and more interesting. If the end-users do most of their own research, library professionals will have time to perform research that requires more expertise. This research should also be more interesting than performing "routine" searches. Information professionals are still in the best position to perform research in the shortest amount of time and at the lowest cost to the firm. More time can also be spent on constructing databases for the end-user. In addition to making commercial CDs and databases available, information professionals must be able to customize information systems to support the research needs of analysts and other end-users. Librarians need to add value to the information they are providing.

The findings show that securities analysts think of themselves as gatekeepers in their organizations. They believe it is their role to obtain information from outside the firm. Information professionals should also think of themselves as gatekeepers. Librarians can serve as gatekeepers by constructing databases of useful contacts and valuable resources both inside and outside of the firm. After all, information professionals have been trained in collecting, accessing, and organizing information.

It also seems that a "virtual library" could change the working habits of information professionals. In addition to making their jobs more interesting, and, hopefully, more important, it could allow librarians to have more flexible work schedules and allow them to work outside of the office.

The construction of a "virtual library" also necessi- 
TABLE 2. Part A: Correlations of Independent with intervening variables.

Information sources and communication channels

Newspap Mags Perfile Commfirm Speakmgt SpeakCEO Indexpt Clubs Comphome Vistoc Dissrept Trades

\begin{tabular}{|c|c|c|c|c|c|c|c|c|c|c|c|c|}
\hline $\begin{array}{l}\text { Individual characteristics } \\
\text { Years of analyst }\end{array}$ & .11 & -.07 & .04 & -.02 & .02 & -.10 & -.21 & .11 & -.11 & $-.35 * *$ & .00 & -.08 \\
\hline No. companies covered & -.06 & -.17 & -.08 & -.04 & .12 & -.08 & .09 & -.05 & .08 & -.02 & .00 & .18 \\
\hline Previous work exp. & .05 & .02 & -.02 & -.10 & .11 & -.05 & -.10 & -.01 & -.13 & -.13 & .00 & .12 \\
\hline Association member & .18 & .16 & -.04 & .20 & -.26 & .10 & $.26^{*}$ & -.03 & .19 & .09 & -.18 & .18 \\
\hline Married w/children & .05 & -.04 & -.02 & -.03 & .03 & .06 & -.02 & .23 & .07 & -.10 & .07 & .21 \\
\hline Sex & .03 & .00 & -.04 & .09 & -.09 & .05 & .03 & .13 & .02 & -.07 & .08 & .11 \\
\hline Age & .13 & .00 & .04 & -.19 & .02 & -.07 & -.15 & .12 & -.10 & $-.32 * *$ & .00 & .00 \\
\hline MBA degree & .11 & .16 & .00 & -.11 & .07 & .17 & .04 & .02 & .08 & -.08 & .05 & .11 \\
\hline $\begin{array}{l}\text { Institutional resources } \\
\text { Have secy/asst }\end{array}$ & $.32 * *$ & .12 & -.05 & .07 & -.11 & $.29 *$ & .20 & -.04 & .07 & -.15 & .05 & -.05 \\
\hline Time/budget conference & -.07 & .00 & .17 & .16 & -.06 & .06 & .08 & .09 & .22 & .08 & -.05 & .09 \\
\hline $\begin{array}{l}\text { Time/budget } \\
\text { tradeshows }\end{array}$ & -.18 & -.07 & .03 & -.03 & .24 & .02 & -.02 & -.09 & -.03 & .01 & -.02 & $-.59 * *$ \\
\hline Full service/regional & -.16 & $-.28 *$ & .00 & .12 & .15 & -.03 & .07 & -.17 & -.09 & .06 & -.15 & $-.40 * *$ \\
\hline Domestic/foreign firm & .17 & $.39 * *$ & .01 & -.09 & -.05 & .05 & .12 & .06 & .15 & $-.33 * *$ & .21 & .05 \\
\hline Firm's capital size & -.13 & $-.35 * *$ & .03 & .10 & .16 & -.03 & .09 & -.21 & -.11 & .00 & -.18 & $-.38 * *$ \\
\hline Use external libraries & .35 & $.39 *$ & .08 & -.24 & .03 & .08 & .19 & .12 & .09 & .03 & .13 & .00 \\
\hline Staff use int library & -.11 & .10 & -.09 & -.12 & -.17 & -.15 & -.02 & .11 & .06 & -.03 & .04 & $.41 * *$ \\
\hline You use int library & -.11 & -.06 & $.30 *$ & .12 & -.04 & -.09 & .06 & -.03 & .03 & -.15 & .19 & .10 \\
\hline Staff use comm dbases & -.16 & -.07 & .12 & -.18 & -.17 & .20 & -.05 & -.01 & -.01 & .05 & .08 & .02 \\
\hline You use comm dbases & .25 & .17 & .01 & .00 & .19 & .06 & .20 & .09 & .22 & -.05 & .20 & .11 \\
\hline
\end{tabular}

$*=p<.01 ; * *=p<.001$.

Part B: Correlation of independent with dependent variables.

\begin{tabular}{|c|c|c|c|c|}
\hline & \multicolumn{4}{|c|}{ Outcomes } \\
\hline & Income & Ranked & No. Reports/mo & Satisfaction \\
\hline \multicolumn{5}{|l|}{ Individual characteristics } \\
\hline Years as analyst & .28 & .21 & $-.25^{*}$ & -.13 \\
\hline No. companies covered & .03 & .11 & .04 & -.13 \\
\hline Previous work exp. & -.01 & .06 & .08 & -.07 \\
\hline Association member & .11 & .10 & -.07 & .08 \\
\hline Married w/children & .00 & .01 & .09 & -.02 \\
\hline Sex & .10 & .05 & .07 & .02 \\
\hline Age & .07 & .11 & -.09 & -.17 \\
\hline MBA & .12 & -.02 & .18 & .03 \\
\hline \multicolumn{5}{|l|}{ Institutional resources } \\
\hline Have secy/asst & .27 & $.27 *$ & -.01 & -.03 \\
\hline Time/budget conference & -.16 & -.15 & -.08 & .08 \\
\hline Time/budget tradeshows & .10 & .03 & -.11 & -.01 \\
\hline Full service/regional & $.51 * *$ & $.44 * *$ & -.10 & .03 \\
\hline Domestic/foreign firm & -.12 & -.19 & .04 & -.06 \\
\hline Firm's capital size & $.47 * *$ & $.42 * *$ & -.16 & .01 \\
\hline Use external libraries & -.07 & -.20 & .02 & -.16 \\
\hline Staff use int library & -.23 & $-.32 * *$ & -.01 & .00 \\
\hline You use int library & -.05 & -.14 & .02 & .08 \\
\hline Staff use comm dbases & .09 & .11 & -.04 & -.07 \\
\hline You use comm dbases & .13 & .04 & .05 & .01 \\
\hline \multicolumn{5}{|c|}{ Information and communication } \\
\hline Newspapers read & .12 & .06 & .08 & -.13 \\
\hline Magazines read & -.22 & -.16 & $.25 *$ & .06 \\
\hline Keep personal files & -.18 & -.14 & -.02 & .00 \\
\hline Comm w/firm analysts & .03 & .09 & .16 & .11 \\
\hline Speak w/ops, mngt & .13 & .20 & .02 & -.26 \\
\hline
\end{tabular}




\begin{tabular}{lccrr}
\hline & \multicolumn{3}{c}{ Outcomes } \\
\cline { 2 - 5 } & Income & Ranked & No. Reports/mo & Satisfaction \\
\hline Speak w/CEO, CFO & .04 & .18 & $.25^{*}$ & .13 \\
Employ industry expert & .06 & .01 & .02 & .02 \\
Member private clubs & .03 & -.02 & .01 & .00 \\
Use computer at home & -.03 & -.01 & .01 & .00 \\
No. co. visits/year & .04 & .01 & .00 & .00 \\
Send reports & -.04 & -.11 & .00 \\
No. days tradeshows & -.16 & & & .03 \\
\hline
\end{tabular}

$*=p<.01 ; * *=p<.001$.

tates the need to work more closely with other technology professionals within the firm. Most corporations have an Information Technology (IT) Department which is responsible for implementing and maintaining the firm's technology. They have the responsibility for rolling out new hardware and software, providing training for new systems and software applications, and maintaining "help desks" to assist the users with technical problems. Since library professionals are also interested in providing "desk top" applications to users, it seems logical that these two groups of information professionals could work closely together or even merge to form one department. Together these two groups could implement technological applications that provide securities analysts and other user groups with the best and most timely information available. In reality this is not happening. The professional culture of the two groups seems to clash. It appears that librarians are trained to be "user-oriented" and provide information to the user, while the IT professionals seem to be more interested in developing and implementing the technology. Each group also appears to be very territorial. But if these two groups can work more closely, it would be to their advantage and the benefit of their user groups.

\section{Implications for Library Schools}

The number of library schools closing in the past several years is an indication that they may no longer understand nor meet the needs of information professionals. In many cases, their curricula have not kept up with the technology being used by knowledge workers. Technology has changed the demands corporations make upon their information centers. For example, corporate libraries no longer have the need or the resources to develop large research collections, nor do they want or need detailed cataloguing. Library schools need to be teaching a new set of skills.

In The Value of Corporate Libraries Study, senior managers were asked what products and services they would like to see provided by libraries. Fifty-three percent wanted all workers to have access to on-line databases via networks, $6 \%$ wanted more end-user training, and
$12 \%$ wanted a connection to the Internet (Matarazzo \& Prusak, 1995, pp. 18-19). These are areas in which information professionals should and can play a major role, if they have adequate computer training. But $21 \%$ of the managers interviewed believed that information professionals needed more technological expertise.

Research collections are being replaced by on-line databases, CD-ROMs, and the Internet. These resources are being made available to end-users via LANs and WANs. Librarians not only need to learn how to select appropriate computerized resources, but they need to be taught the technical skills that are necessary to use these resources, and the communication and teaching skills necessary to promote these services, and train the end-users. If librarians have better technical skills, they may also be able to work more closely, and improve their relations, with their firm's Information Technology Department.

Working librarians need to update their technological skills through continuing education courses and seminars offered by library schools, programs and conferences presented by professional associations, and frequent communication with publishers and vendors. Through this ongoing learning process, information professionals will be able to use their technical knowledge and subject expertise to bring timely information to securities analysts and other groups of information seekers.

\section{Limitations}

A question about the representativeness of the final sample remains. A small number of the 166 analysts could not be reached because they had left the firm. In most instances, these analysts had been hired by another investment firm. It could be argued that these were the more successful analysts because they had been hired away by a competitor firm. This would leave the more successful analysts under-represented in this sample. But considering the large number of Institution Investor ranked analysts included in the sample, this does not seem likely. Alternatively, it could be argued that the 166 analysts who did not participate in the study were less successful analysts. It could be argued that these analysts could not be both- 
ered to participate because they were lazy. Again, this does not seem likely, as most of these did not refuse, but did not have the time at that moment, or were not available. Although it is possible that the 100 analysts are not a representative sample, there is no evidence that this is the case.

Another question concerns a possible bias toward institutional resources due to their association with individual characteristics. As shown in the theoretical model, this study separates individual influences from institutional influences. The individual variables and the institutional variables are measured in the same canonical correlations which conceptually separates the two influences, but does

TABLE 3. Part A: Standardized structure coefficients (variate loadings) and canonical correlations for the influences of individual characteristics and institutional resources on information sources and communication channels.

\begin{tabular}{lcc}
\hline \multicolumn{1}{c}{ Independent variables } & Variate I & Variate II \\
\hline Individual & & \\
$\quad$ Analyst - years experience & -.02 & -.34 \\
Membership in associations & .11 & .35 \\
Institutional & .04 & .60 \\
$\quad$ Staff & .73 & .02 \\
Costs - time and budget & .11 & -.75 \\
Type of firm (regional) & .19 & .61 \\
Size of firm & -.39 & .05 \\
Use of internal libraries by analyst & & \\
\hline \multicolumn{1}{c}{ Dependent variables } & & \\
\hline Channels & -.19 & .52 \\
Read newspaper & .30 & .48 \\
External communication & .09 & .45 \\
External information & -.90 & -.13 \\
Attend annual meetings \& trade shows & .58 & .46 \\
Squared canonical correlation & $F=2.30^{*}$ & $F=1.78^{*}$ \\
Wilks' lambda & &
\end{tabular}

$*=p \leq .05 ; N=77$.

Part B: Standardized structure coefficients (variate loadings) and canonical correlation for the influence of information sources and communication channels on outcomes ${ }^{\mathrm{a}}$.

\begin{tabular}{lc}
\hline \multicolumn{1}{c}{ Independent variables } & Variate I \\
\hline $\begin{array}{l}\text { Internal communication } \\
\text { Keep personal files }\end{array}$ & -.57 \\
$\begin{array}{l}\text { External communication } \\
\text { Speak with executives of companies }\end{array}$ & .82 \\
\hline \multicolumn{1}{c}{ Dependent variables } & \\
\hline Outcomes & .94 \\
Ranked & .43 \\
Number reports & .20 \\
Squared canonical correlation & $F=1.51^{\text {ns }}$ \\
Wilks' lambda & \\
\hline \multicolumn{2}{c}{$N=22}$.
\end{tabular}

TABLE 4. Standardized structure coefficients (variate loadings) and partial canonical correlations for the influence of individual characteristics and institutional resources on outcomes, controlling for the influence of information sources and communication channels.

\begin{tabular}{lc}
\hline \multicolumn{1}{c}{ Independent variables } & Variate I \\
\hline Individual & .59 \\
$\quad$ Analyst_-years worked & \\
Institutional & .34 \\
Staff size & .49 \\
Type of firm (full service) & -.34 \\
Use of internal libraries by analyst and staff & \\
\hline
\end{tabular}

Dependent variables

$\begin{array}{lc}\text { Outcomes } & .78 \\ \text { Ranked } & -.37 \\ \text { Number reports published } & .40 \\ \text { Squared partial canonical correlation } & F=1.53^{*} \\ \text { Wilks' lambda }\end{array}$

$$
*=p \leq .05 ; N=33 \text {. }
$$

not preclude the influence of either. In retrospect, there might be an argument that these variables are related in various ways, such as that successful analysts seek out, or are sought out, by larger, domestic full-service firms where, in turn, analysts gain the benefits of greater resources. We used correlations to test for any relation between the individual variables and the institutional variables in domestic full-service and regional firms. As it turns out, there are few significant relations among individual influences and institutional resources, except that analysts who have a support staff work more hours ( $r=$ $.30, p<.01)$ and analysts who work at domestic firms belong to more associations $(r=.32, p<.01)$ and are more likely to have an M.B.A. $(r=.35, p<.001)$. However, none of the individual variables is associated with type of firm.

\section{Suggestions for Future Research}

As this study only includes industry analysts in U.S.based firms, it would be valuable to explore the research habits of other types of sell-side analysts. A similar study of country analysts and analysts who work for non-U.S.based firms would make a useful comparison. This study should have a larger sample of foreign securities analysts, including those working in Tokyo and Hong Kong. A further extension of this study could compare the information-seeking behavior of sell-side analysts with the buyside analysts who work as portfolio managers in institutions.

The finding that institutional resources have a significant influence on the information/communication channels analysts use, and thereby play a significant role in analysts' information activities, deserves further exploration. In particular, the findings that securities analysts are 
not heavy users of their internal libraries, and that for those analysts who do use their internal libraries, library usage is not a guarantee of success, merit further investigation. A study of how information professionals can provide support to this group of information-seekers, and in particular, how their support may help make securities analysts more successful, would be useful to analysts and information professionals. The study could focus on "desk top" applications that can add "value" to analysts' research. Applications such as CD-ROMs, internal and external databases, the Internet, E-mail, and video-conferencing could be investigated.

\section{References}

Aguilar, F. J. (1967). Scanning the business environment. New York: Macmillan.

Allen, T. J. (1969). Information needs and uses. In C. A. Cuadra (Ed.), Annual review of information science and technology, Vol. 4 (pp. $3-$ 29). Chicago: Encyclopedia Britannica.

Allen, T. J. (1977). Managing the flow of technology: Technology transfer and the dissemination of technological information within the $R \&$ $D$ organization. Cambridge: MIT Press.

A. P. A. (1963). Project on scientific information exchange in psychology. Washington, DC: American Psychological Association.

Bent, B., \& Halliday, L. (1990, April). Ranking America's biggest bankers. Institutional Investor, pp. $91 \mathrm{ff}$.

Berelson, B. (1949). The library's public. New York: Columbia University Press.

Berney, K. (1990, July). Get ready for the quality generation. International Management, 45, 26-33.

Bretz, R. D., Jr. (1989, Spring). College grade point average as a predicator of adult success: A meta-analytic review and some additional evidence. Public Personnel Management, 18, 11-22.

Campbell, M. J. (1975, November-December). Structure and distribution of business information: Some problem areas. Aslib Proceedings, 329.

Cannings, K. (1988, October). Managerial promotion: The effects of socialization, specialization, and gender. Industrial \& Labor Relations Review, 42, 77-88.

Cartter, A. M. (1966). Assessment of quality in graduate education. Washington, DC: American Council on Education.

Chang, L. S. (1981). Financial analysts and financial statements. Sweetwater, FL: Florida International University. (unpublished doctoral dissertation)

Chen, C.-C., \& Hernon, P. (1982). Information seeking: Assessing and anticipating user needs. New York: Neal-Schuman.

Choo, C. W., \& Auster, E. (1993). Environmental scanning: Acquisition and use of information by managers. In M. Williams (Ed.), Annual review of information science and technology, Vol. 28 (pp. 279-314). Medford, NJ: Learned information.

Cole, S., \& Cole, J. R. (1967, August 28-31). Visibility and the structural bases of observability in science. Paper presented before the American Sociological Association, San Francisco.

Collings, R. F. (1968). Scanning the environment for strategic information. Unpublished doctoral dissertation, Harvard Business School, Cambridge, MA.

Crane, D. (1971). Information needs and uses. In C. A. Cuadra (Ed.), Annual review of information science and technology, Vol. 6 (pp. 339). Chicago: Encyclopedia Britannica.

Crawford, S. (1978). Information needs and uses. In M. Williams (Ed.), Annual review of information science and technology, Vol. 13 (pp. 61-81). White Plains, NY: Knowledge Industry Publications.

Cronin, B. (1982). Invisible colleges and information transfer: A review and commentary with particular reference to the social sciences. Journal of Documentation, 38(3), 212-236.

Danzig, F., \& Wells, M. (1993, May 24). "Old boys' network" still alive. Advertising Age, p. 40.

Dervin, B. (1976). The everyday information needs of the average citizen: A taxonomy for analysis. In M. Kochen \& J. Donahue (Eds.), Information for the community (pp. 23-35). Chicago: American Library Association.

Dorfman, J. (1994a, June 29). Analysts' pay set a record last year. Wall Street Journal, p. R9.

Dorfman, J. (1994b, June 29). Industry by industry, here is what the All-Stars think now. Wall Street Journal, p. R3.

Dorfman, J. (1994c, June 29). Second helping of glory goes to more than 100 All-Stars. Wall Street Journal, p. R11.

Dorfman, J. (1995a, June 20). How the analysts are ranked. Wall Street Journal, p. R6.

Dorfman, J. (1995b, June 20). How the survey is conducted. Wall Street Journal, p. R7.

Drott, C. (1973). Models and measurements of user information needs in the selection of systems for the selective dissemination of information. Unpublished doctoral dissertation, University of Michigan, Ann Arbor.

Dunn, R. (1993, October 21). Benchmarking your income. Plant Engineering, 47, p. 64.

Durrance, J. (1984). Armed for action: Library response to citizen information needs. New York: Neal-Schuman.

Dychtwald, K. (1990, February). The age wave. Training \& Development Journal, 44, 22-31.

Extel Financial (1993). Ranking of investment analysts: 1993 20th annual survey. London: Extel Financial Limited.

Fisher, A. (1992, November 30). Welcome to the age of overwork. Fortune, 126, pp. $64 \mathrm{ff}$.

Ford, G. (1973, March). Progress in documentation: Research in user behaviour in university libraries. Journal of Documentation, pp. 85106.

Friedlander, J. (1973, Jan-Feb). Clinician search for information. Journal of the American Society for Information Science, 24, pp. 65-69.

Garvey, W. D., \& Griffith, B. (1968). Informal channels of communication in the behavioral sciences: Their relevance in the structuring of formal or bibliographic communication. In E. B. Montgomery (Ed.), The foundations of access to knowledge (pp. 129-151). Syracuse, NY: Syracuse University.

Geyer, C. T. (1969, January). An institution's best friend can be its trader. Institutional Investor, p. 35.

Gillis, J. G. (1985, July-August). Soft dollars and investment research. Financial Analysts Journal, pp. 16-17.

Givoly, D., \& Lakonishok, J. (1984, September-October). The quality of analysts' forecasts and earnings. Financial Analysts Journal, pp. $40-47$.

Grosser, K. (1991). Human networks in organizational information processing. In M. Williams (Ed.), Annual review of information science and technology, Vol. 26 (pp. 349-402). Medford, NJ: Learned Information.

Hart, P., \& Rice, R. E. (1991). Using information from external databases: Contextual relationships of use, access method, task, database type, organizational differences and outcomes. Information Processing and Management, 27(5), 461-479.

Hofer, C. W. (1976). Research on strategic planning: A survey of past studies and suggestions for future efforts. Journal of Economics and Business, 28, 261-286.

Johns Hopkins University (1969, June). Reports of studies of the publication fate of material presented at the national meetings: Two years after the meetings. Baltimore: Center for Research in Scientific Communication.

Jones, R. (1990, May). What's a PhD worth? Try $\$ 2$ million. $R \& D$, $32,82-87$.

Katzer, J., \& Fletcher, P. (1992). The information environment of managers. In M. Williams (Ed.), Annual review of information science 
and technology, Vol. 27 (pp. 227-263). Medford, NJ: Learned Information.

Keegan, W. J. (1967). Scanning the international business environment: A study of the information acquisition process. Unpublished doctoral dissertation, Harvard Business School, Cambridge, MA.

Kleinfield, N. R. (1985, October 27). The many faces of the Wall Street analyst. New York Times, late ed., sec. 3: 1.

Ladendorf, J. M. (1970). Information flow in science, technology and commerce: A review of the concepts of the sixties. Special Libraries, $61,215-222$.

Lamont, T. (1995, January 9). Analyst population grew in 1994 says Nelson. Wall Street Letter, p. 6.

Latane, H., \& Tuttle, D. (1970). Security analysis and portfolio management. New York: Ronald Press.

Lewis, J. (1989). The rise of woman power. Institutional Investor, 23, $176-182$.

Lohr, S. (1986, October 28). 'Big Bang' opens in London. New York Times, p. D1.

Market \& Opinion Research International (1990). Institutional investors and analysts in Great Britain - report to participants 1990. London: MORI.

Matarazzo, J. M., \& Prusak, L. (1995). The value of corporate libraries: Findings from a survey of senior management. Washington, D.C.: Special Libraries Association.

Mattlin, E. (1969, July). How do you measure an analyst's performance? Institutional Investor, p. 37.

Meisler, L., \& Bent, B. (1992, March). The 1992 All-Europe research team. Institutional Investor, pp. 93-98.

Meisler, L., \& Bent, B. (1994, October). The 1994 All-America research team. Institutional Investor, p. 77.

Meisler, L., \& Bent, B. (1995, October). The 1995 All-Europe research team. Institutional Investor, p. 97.

Menzel, H. (1966). Information needs and uses in science and technology. In C. A. Cuadra (Ed.), Annual review of information science and technology, Vol. 1 (pp. 41-69). New York: Interscience Publishers.

Merton, R. (1968, January). The Matthew effect in science. Science, 159 , pp. 56-63.

Metoyer-Duran, C. (1993). Information gatekeepers. In M. Williams (Ed.), Annual review of information science and technology, Vol. 28 (pp. 111-150). Medford, NJ: Learned Information.

Moore, P. (1992, September). European brokers survey 1992. Euromoney, Supp: 1.

Muchinsky, P. M. (1978). Age and job facet satisfaction: A conceptual reconsideration. Aging and Work, 1, p. 175.

Nelson, W. R. (Ed.). (1989, March). Most heavily researched industries named in Nelson's annual survey. Nelson's Research Monthly, p. 1.

Nelson, W. R. (Ed.). (1995, March). Nelson's catalog of institutional research reports. Global Edition. Port Chester, New York: Nelson.
Nicholas, D., Erbach, G., \& Paalman, K. (1987a, August). Big bang: The information lessons learnt. Online Review, pp. 219-239.

Nicholas, D., Erbach, G., \& Paalman, K. (1987b). Online searching: Its impact on information users. London: Mansell.

Nudell, M. (1992, September). Expose yourself for career success. Security Management, 36, 80-81.

Prentice, A. (1980). Information seeking patterns of selected professionals. Public Library Quarterly, 2(1), 27-60.

Price, D. J. deSolla (1963). Little science, big science. New York: Columbia University.

Rhodes, S. R. (1983). Age-related differences in work attitudes and behaviors: A review and conceptual analysis. Psychological Bulletin, 93(2), 328-367.

Rider, B. (Ed.), (1987). Financial services reporter, 3 vols. London: CCH Editions Limited.

Rosenbloom, R. S., \& Wolek, F. (1967). Technology, information, and organization: Information transfer in industrial $R \& D$. Boston: Graduate School of Business Administration, Harvard University.

Rosenbloom, R. S., \& Wolek, F. (1970). Technology and information transfer: A survey of practice in industrial organizations. Boston: Graduate School of Business Administration, Harvard University.

Selig, G. (1982, June). Approaches to strategic planning for information resource management (IRM) in multinational corporations. MIS Quarterly, pp. 33-45.

Shilling, C. W., Bernard, J., \& Tyson, J. (1964). Informal communication among bioscientists. Washington, DC: Biological Sciences Communication Project, George Washington University.

Smith, P. L., \& Hoy, F. (1992, October). Job satisfaction and commitment of older workers in small business. Journal of Small Business Management, 30, 106-130.

Stevenson, H. H. (1969). Defining corporate strengths and weaknesses: An exploratory study. Unpublished doctoral dissertation, Harvard Business School, Cambridge, MA.

Top analysts spend almost half their time marketing. (1986, March 24). Wall Street Letter, p. 1.

Uchitelle, L. (1993, January 11). In economics, a subtle exclusion. The New York Times, p. 1.

White, R. (1976, August). Wall Street's 'other' analysts. Institutional Investor, pp. 35-36.

Wilson, P. C. (1977). A community elite and the public library: The uses of information in leadership. Westport, CT: Greenwood Press.

Wipperfurth, H. (1995, January 2). Semi-annual research survey. Securities Week, p. 1.

Zweizig, D., \& Dervin, B. (1977). Public library use, users, uses: Advances in knowledge of the characteristics and needs of the adult clientele of American public libraries. In M. J. Voigt \& M. H. Harris (Eds.), Advances in librarianship, Vol. 7 (pp. 231-255). New York: Academic Press. 